\title{
Households Vulnerability to Climate Change in Drought Prone Agro-ecosystems of Northeastern Ethiopia
}

\author{
Endalew Addis ${ }^{1} \quad$ Workneh Negatu ${ }^{2} \quad$ Belay Simane ${ }^{2}$ \\ 1.Hawassa University, College of Social Sciences and Humanities, Hawassa, Ethiopia \\ 2.Addis Ababa University, College of Development Studies, Addis Ababa, Ethiopia
}

\begin{abstract}
Climate change is seriously affecting households who are mainly depending on rain-fed farming agriculture and pastoral/agro-pastoral way of life in different agro-ecosystems. Hence, households' level of vulnerability analysis to climate change is very important to know the vulnerability of local households in different agro-ecosystems so as to tap their potentials for climate change adaptation at the grass root level. Accordingly, this article examined climate change vulnerability of households in highland mixed farming, lowland mixed farming, agro-pastoral, and pastoral agro-ecosystems in drought prone areas of northeastern Ethiopia focusing on Kobo and Golina districts in Amhara and Afar regions respectively. Data gathered from secondary sources, observation, key informant interviews, focus group discussions, and household survey to address the problem comprehensively. Consequently, quantitative data analyzed by SPSS and STATA software whereas qualitative information analyzed by thematic analysis. More specifically, two analytical models used to perform quantitative analysis. Firstly, principal component analysis used to calculate adaptive capacity, sensitivity, exposure and vulnerability indexes of households in each agro-ecosystem. Secondly, ordered probit model fitted to examine the determinants of highly, moderately and less vulnerable categories of households at each agro-ecosystem. The findings have shown that while households in lowland mixed farming agro-ecosystem are less vulnerable, households in agro-pastoral agroecosystem are more vulnerable. However, not all households in lowland mixed farming agro-ecosystems are less vulnerable and not all households in agro-pastoral agro-ecosystems are more vulnerable. Hence, it is recommended that households' specific adaptive capacity should be improved through mainly empowering female-headed households, expanding education, developing irrigation schemes, and creating access to affordable credit and appropriate extension services in the study areas as it reduces their sensitivity and finally their overall vulnerability. Keywords: climate change, vulnerability, drought-prone, principal component analysis, ordered probit
\end{abstract} DOI: $10.7176 /$ JNSR/13-5-05

Publication date:March $31^{\text {st }} 2021$

\section{INTRODUCTION}

Climate change is one of the greatest challenges facing the international community in the $21^{\text {st }}$ century (Mearns and Norton, 2010). This is because, multiple independent data sources confirm beyond any reasonable doubt that the Earth's surface warmed during the $20^{\text {th }}$ century, and it is virtually certain that the Earth will continue to warm in the $21^{\text {st }}$ century (Dessler and Parson, 2006). This climate change has impacts such as droughts, floods, and forest fires, which causes lose of homes, crop failures, reduced agricultural productivity, increased hunger, malnutrition, and disease (WDR, 2010) on different countries showing that no country is immune from various impacts of climate variability and change. Africa is highly vulnerable to climate change and climate variability as the majority of the populations depend on subsistence rain-fed agriculture (Boko et al., 2007); for instance, 85 percent of the population in Ethiopia depends on rain-fed agriculture (MOFED 2008 cited in Deressa, 2010). Furthermore, climate change impacts are more serious in drylands as they are characterized by limited water resources, and seasonal, scarce and unreliable rainfall; poorly served by infrastructures; and affected by periodic droughts (Anderson et al., 2010).

Ethiopia as one of the sub-Saharan country is most vulnerable to climate change impacts mainly due to frequent droughts and floods with the least capacity to respond (Di Falco et al., 2011). For instance, since the early 1980s, Ethiopia has suffered seven major droughts of which five led to famines (World Bank, 2010). More specifically, the major droughts occurred in late 1950s in northern parts of Ethiopia, in 1972/73 in northeastern part of Ethiopia in Tigray and Wollo, in 1984/85 in major parts of the country, in 1994 in pastoral areas of Ethiopia, in 2000 in southern lowland pastoral areas of Ethiopia, in 2002/3 in major parts of the country, and in 2007/8 in many highland and lowlands areas of Ethiopia (World Bank, 2010). Of these, the 1984/85 drought reduced Ethiopia's agricultural production by 21 percent, which led to a 9.7 percent fall in the GDP (World Bank, 2006). Crop and livestock losses over northeastern Ethiopia, associated with droughts during 1998-2000, estimated at US\$266 per household, which is greater than the average annual income for 75 percent of households in this region (Stern, 2007). Thus, given the nature of Ethiopia's economy, which largely depends on weather-sensitive and small-scale agricultural practices and the low adaptive capacity of poor farm households, the potential adverse effects of climate change on crop agriculture and food security will be increasing through time (Balew et al., 2014), as Ethiopia has also suffered from drought due to El Nino in 2015/16. This shows that for developing countries 
like Ethiopia, climate change threatens to deepen vulnerabilities, erode hard-won gains, and seriously undermine prospects for development (WDR, 2010).

Accordingly, assessing vulnerability is a starting point for promoting remedial action, limiting impacts, supporting coping strategies and facilitating adaptation (Kelly and Adger, 2000); and can help answer where and how society best can invest to reduce vulnerability (Mearns and Norton, 2010). Moreover, effective planning for adaptation requires a fine-grained assessment of local vulnerabilities, practices and adaptation options and preferences (Kuriakose et al., 2009). To this end, some studies (Tadesse et al., 2008; Gebremichael and Kifle, 2009; Bewket, 2012; Tesso et al., 2012; Simane et al., 2013; Simane et al., 2014; Teshome, 2014) have been done in Ethiopia.

However, though most of the droughts occurred in the northeastern Ethiopia and the areas are more vulnerable to climate change impacts; climate change vulnerability of households in different agro-ecosystems is not well addressed as there are gaps in the study areas covered, unit of analysis employed and the methodologies applied. As to the study areas covered, Tesso et al. (2012) studied vulnerability and resilience to climate change induced shocks in North Shewa, Ethiopia, taking highland, midland and lowland agro-ecologies within the same livelihood system, but not households in agro-ecosystems with different livelihood strategies. Bewket (2012) has assessed climate change perceptions and adaptive responses of smallholder farmers in central highlands of Ethiopia but not by comparing with lowland smallholder farmers, agro-pastoralists and pastoralists. Negatu et al. (2011) assessed the vulnerability of Borana agro-pastoralists and pastoralists in the southern part of Ethiopia but with a different cultural setting. Moreover, even in those few studies (Hadgu et al., 2015; Deressa, 2010) done in drought prone areas of northeastern Ethiopia, there are gaps in the unit of analysis employed. For instance, a study conducted by Tadesse (2010) has assessed vulnerability to climate change and adaptation responses using region as a unit of analysis in which, within the region there is a great variation from one agro-ecosystem to the other; and households in those agro-ecosystems should be addressed separately to design context specific adaptation strategies. Furthermore, there are gaps in the methodology applied in some of those studies. Tadesse (2010) has assessed vulnerability to climate change and adaptation responses only using quantitative approaches where as Gebremichael and Kifle (2009) has assessed vulnerability using qualitative methods only. However, both qualitative and quantitative approaches have their own strengths and weaknesses. In addition, though there are some studies conducted in Ethiopia using PCA (Tesso et al., 2012; Tadesse, 2010), they are conducted in different areas and they are not addressing households in different agro-ecosystems with different livelihood systems.

The purpose of this research, therefore, is to study households' vulnerability to climate change in highland and lowland mixed farming, agro-pastoral and pastoral agro-ecosystems in drought prone areas of northeastern Ethiopia to use as an input to design appropriate adaptation strategies that increase the resilience of households. In so doing, the study aims at describing the environmental contexts of households in highland mixed farming, lowland mixed farming, agro-pastoral, and pastoral agro-ecosystems; examining households' vulnerability to climate change; and analyzing various factors influencing the vulnerability of these households to climate change.

\section{METHODOLOGY}

\section{Description of the Study Sites}

The study is conducted in Kobo and Golina (two bordering districts) in the Amhara and Afar regions respectively in northeastern part of Ethiopia representing different agro-ecosystems (Figure 1). Agro-ecosystems mainly consist of agro-ecology and farming systems. Ethiopia has five traditional agro-ecological zones: bereha (desert, below 500 m.a.s.1.), kola (lowland, 500 to 1500 m.a.s.1.), weynadega (middle land, 1500 to 2500 m.a.s.1.), dega (highland, 2500 to 3500 m.a.s.1.), and Wurch (above 3500 m.a.s.1.) (MOA, 2000). The study districts fall in three of them (kola, weynadega and dega). Kobo is classified as highland and lowland with an altitude ranging from 1000 to 3000 m.a.s.1. (Woreda Agricultural Development Office, 2013); and received an average annual rainfall of 750 $\mathrm{mm}$ and mean annual maximum and minimum temperature of 25 and $12^{\circ} \mathrm{C}$, respectively (NMA, 2012). On the other hand, Golina district comprised of two major agro-ecological zones. A smaller portion lies in the desert with an elevation of less than $500 \mathrm{~m}$ while a greater portion lay in the lowland with elevation between 500 and $650 \mathrm{~m}$ (Woreda Pastoral Development Office, 2013). This study considers the lowland characterized with mean annual maximum and minimum temperature of 37 and $22^{\circ} \mathrm{C}$, respectively and average annual rainfall of $200 \mathrm{~mm}$ (NMA, 2012). 
Figure 1: Map of the Study Sites

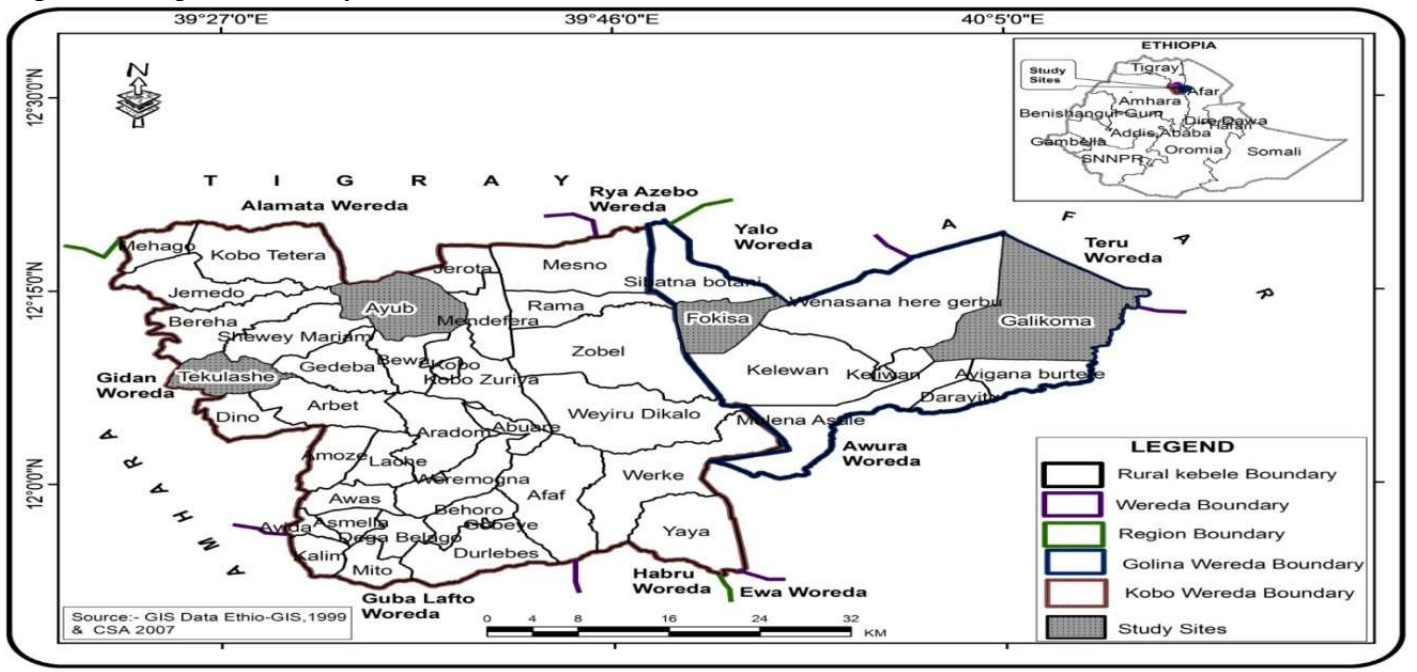

On the other hand, there are four major farming systems in Ethiopia: seed-farming, enset-planting, shifting cultivation, and pastoral complexes. The seed-farming complex focuses on grain production in the central, northern, and eastern highlands involving the majority of Ethiopian small farmers. Shifting cultivation and pastoral complexes are most common in the western and eastern lowlands, respectively (Westphal, 1975 cited in Chamberlin and Schmidt, 2011). Kobo district in the Amhara region is found in seed farming system (i.e., croplivestock mixed farming), characterized by various constraints mainly moisture scarcity due to rainfall variability, reduction of soil fertility, occurrence of crop pests and diseases, and shortage of farmland (Amhara Bureau of Agriculture, 2014). Golina district is found in pastoral farming system in Afar region. The Afar pastoralists pursue their livelihoods in subsistence based, mixed livestock management of camels, cattle, goats and sheep (PCDP, 2005). However, crop production is a newly emerging livelihood system in Golina district in Afar pastoral system. As a result, agro-pastoral farming system (crop production and livestock raising) is included in this study to get a complete picture of agro-ecosystem level analysis of climate change vulnerabilities in the study areas.

\section{Data Collection}

A combination of qualitative and quantitative research methods applied to overcome various weaknesses inherent in different methods (Dawson, 2009). Mixed research approach, therefore, employed to collect quantitative and qualitative data. Accordingly, household survey, observations, key informant interviews, focus group discussions, and secondary data analysis used iteratively to collect both primary and secondary data for this study. Temperature and rainfall station recorded data of the study areas and nearby stations from 1980 to 2010 obtained from National Meteorological Agency. Direct observation of the study sites conducted to look at the environmental, socioeconomic and institutional contexts. Key informant interviews conducted with representatives of Ministry of Environmental Protection and Forestry, Ministry of Agriculture, Ministry of Federal Affairs, Pastoralist Forum Ethiopia, and Climate Change Forum Ethiopia at the federal level. Moreover, representatives of different regional sectoral offices of Amhara and Afar regional states, local government officials and experts of the study districts, development agents of the study kebeles (the lowest administrative unit in Ethiopia), and households of both sexes at each agro-ecosystem interviewed. Fourteen focus group discussions ( 7 at each district) are conducted. The first FGD conducted with local government officials from different sectors (such as agriculture, environmental protection, water, health, education and women's affair) at district level for highland and lowland mixed farming, and agro-pastoral and pastoral agro-ecosystems. Then, three FGDs conducted with local community workers (development agents, teachers and health extension workers), male households, and female households for each agro-ecosystem.

The study districts were selected purposively to compare climate change vulnerability households being found in drought prone areas bordering each other. Since both districts have more or less proportional number of rural kebeles by agro-ecosystem, one rural kebele, representing each agro-ecosystem selected randomly. Finally, households selected using systematic sampling technique proportionately.

The study has employed the following formula to determine the sample size (Lohr, 2010). Accordingly, to obtain absolute precision $\mathrm{e}$, find the value of $\mathrm{n}$ that satisfies:

$$
e=z \alpha / 2 \sqrt{\left(1-\frac{n}{N}\right) \frac{S}{\sqrt{n}}}
$$


To solve this equation for $\mathrm{n}$, first find the sample size $n_{0}$

$$
\text { Where } \begin{aligned}
& n=\text { required sample size } \\
& z_{\alpha}^{2} / 2=1.96^{2} \\
& N=\text { the population size }=4530 \\
& S^{2} \approx P(1-p) \text {, which attains its maximum value when } \mathrm{p}=1 / 2 \\
& e=\text { marginal error, usually for many surveys using a proportion, } \mathrm{e}=0.03 \\
& \alpha=\text { level of significance, usually for many surveys using a proportion, } \alpha=0.05
\end{aligned}
$$

$$
\begin{gathered}
n_{0}=\left(\frac{z \alpha / 2}{e}\right)^{2}, \text { then } \\
n=\frac{n_{0}}{1+\frac{n_{0}}{N}} \\
n=\frac{z_{\alpha}^{2} / 2 S^{2}}{e^{2}+\frac{z_{\alpha}^{2} / 2}{N} S^{2}}
\end{gathered}
$$

Finally, $n_{0}=\frac{(1.96)^{2}\left(\frac{1}{2}\right)\left(1-\frac{1}{2}\right)}{(0.03)^{2}} \approx 1067$

$$
n=\frac{n_{0}}{1+\frac{n_{0}}{N}}=\frac{1067}{1+\frac{1067}{4530}}=864
$$

Lohr (2010) has also pointed out that the final decision to set the sample size is up to the researcher based on

\begin{tabular}{|c|c|c|c|c|c|c|}
\hline Region & Zone & District & Agro-ecosystem & Rural kebele & No of $\mathrm{HHs}^{*}$ & No of selected HHs \\
\hline \multirow[t]{2}{*}{ Amhara } & North & Kobo & Highland Mixed Farming & Tekulashe & 1769 & 169 \\
\hline & Wollo & & Lowland Mixed Farming & Ayub & 1899 & 181 \\
\hline \multirow[t]{2}{*}{ Afar } & Zone 4 & Golina & Agro-pastoral & Fokisa & 513 & 49 \\
\hline & & & Pastoral & Galikoma & 349 & 33 \\
\hline \multicolumn{2}{|c|}{ Total } & 2 & 4 & 4 & 4530 & 432 \\
\hline
\end{tabular}
the existing situation. More specifically, the same source has indicated that though the larger the sample the smaller is the sampling error, some adjustments can be done to reduce non-sampling error, based on the availability of the budget, and to control selection and measurement bias (Lohr, 2010). Accordingly, the sample size for this study adjusted to 432 due to the aforementioned factors.

Accordingly, as presented in Table 1, a total sample size of 432 households (169 from highland mixed farming, 181 from lowland mixed farming, 49 from agro-pastoral, and 33 from pastoral agro-ecosystems) are included in the survey using stratified proportionate sampling formula.

$$
\begin{gathered}
\text { Total sample } n=n_{1}+n_{2}+\cdots+n_{k} \\
n=\left(\frac{1769}{4530}(432)+\frac{1899}{4530}(432)+\frac{513}{4530}(432)+\frac{349}{4530}(432)\right) \\
\mathbf{n}=\mathbf{1 6 9}+\mathbf{1 8 1}+\mathbf{4 9}+\mathbf{3 3}=\mathbf{4 3 2}
\end{gathered}
$$

Table 1: Sampling Distribution

* Source: Respective Agricultural/Pastoral Development Offices, 2013

However, from 432 questionnaires, 6 of them were not included in the analysis due to various problems. Accordingly, a total sample size of 426 households (165 from highland mixed farming, 180 from lowland mixed farming, 48 from agro-pastoral, and 33 from pastoral agro-ecosystems) are included in the analysis.

\section{Modeling and Data Analysis Analytical Model}

There are biophysical, socioeconomic, and integrated approaches for vulnerability analysis of climate change while the integrated assessment approach combines both the biophysical and socioeconomic attributes (Füssel, 2007). Hence, the latter is preferred for this study to examine both the biophysical and socio-economic vulnerabilities.

Accordingly, this study analyzes households vulnerability based on the integrated approach by making use of vulnerability indexes. In so doing, indicators chosen based on literature review and adjusting to the context of the study areas. However, in calculating the direction of relationship in vulnerability indicators (that is, their sign), a negative value was assigned to both exposure and sensitivity. The justification is that households that are highly exposed to climate shocks are more sensitive to damage, assuming constant adaptive capacity. Consequently, 
vulnerability to climate change calculated as net effect of adaptive capacity, sensitivity, and exposure (IPCC, 2001).

Vulnerability $=($ Adaptive Capacity) - (Sensitivity) - (Exposure)..... (1)

In such relationship, higher net value indicates that a household is less vulnerable to climate change and vice versa.

Indicators of sensitivity, exposure and adaptive capacity encompass a wide range of biophysical and socioeconomic aspects of vulnerability that are not necessarily directly comparable (Adger, 2006). While each individual indicator may be of interest to researchers/policymakers, in isolation they might not provide a clear understanding of composite (or aggregate) vulnerability (Abson et al., 2012). Moreover, weights should be assigned to those indicators through different techniques. Livelihood Vulnerability Index (LVI) or Livelihood Vulnerability Index combined with IPCC's three contributing factors to vulnerability, i.e., exposure, sensitivity, and adaptive capacity (LVI-IPCC) follows equal weighting (Hahn et al., 2009). However, it is too arbitrary and leads to overweighting of some less important indicators while underweighting the important ones. The other weighting can be based on expert judgment (Vincent, 2007; Adger and Vincent, 2005; Vincent, 2004); however, this approach criticized for being too subjective and often constrained by the availability of subject matter specialists or lack of consensus among the experts themselves (Gbetibouo, 2009). Assigning weight by Principal Component Analysis (PCA) following Filmer and Pritchett (2001) is thus preferred compared to the former two methods (Cutter et al., 2003).

PCA is a multivariate technique, a number of related variables transformed to a smaller set of uncorrelated variables called principal components (Jackson, 2003). To this end, suppose there are a set of $Z$-variables $\left(a_{1 j}^{*}\right.$ to $\left.a_{z j}^{*}\right)$ that represents the attributes of each household $j$. PCA starts by specifying each variable normalized by its mean and standard deviation since different units measure different indicators. For instance, $a_{1 j}=\left(a_{1 j}^{*}-\right.$ $\left.a_{1}^{*}\right) / s_{1}^{*}$ where $a_{1}^{*}$ is the mean of $a_{1 j}^{*}$ across households and $s_{1}^{*}$ is its standard deviation. The relevant variables for adaptive capacity, sensitivity and exposure expressed as linear combinations of a set of underlying components for each household $j$ :

$$
\begin{gathered}
a_{1 j}=C_{11} V_{1 j}+C_{12} V_{2 j}+\cdots+C_{1 z} V_{z j} \\
j=1 \ldots J \\
a_{z j}=C_{z 1} V_{1 j}+C_{z 2} V_{2 j}+\cdots+C_{z z} V_{z j} \ldots \ldots \ldots \ldots \ldots \ldots \ldots \ldots \ldots \ldots \ldots \ldots \ldots \ldots \ldots
\end{gathered}
$$

Where the $V$ 's are the components and the $C$ 's are the coefficients on each component for each variable. Since only the left side of each line observed, the solution to the problem is indeterminate. PCA overcomes this indeterminacy by finding the linear combination of the variables with maximum variance (usually the first principal component $\mathrm{V}_{1 \mathrm{j}}$ ), then finding a second linear combination of the variables orthogonal to the first and with maximal remaining variance, and so on. Accordingly, the procedure solves the equations $(\mathrm{R}-\lambda \mathbf{I}) \mathrm{v}_{n}=0$ for $\lambda_{n}$ and $\mathrm{v}_{n}$, where $\mathbf{R}$ is the matrix of correlations between the scaled variables (the $a$ 's) and $\mathrm{v}_{n}$ is the vector of coefficients on the $n^{\text {th }}$ component for each variable. Solving the equation yields the eigenvalues of $\mathbf{R}, \lambda_{n}$ and their associated eigenvectors, $\mathrm{v}_{n}$. The final set of estimates produced by scaling the $\mathrm{v}_{n} \mathrm{~s}$ so that the sum of their squares sums to the total variance, another restriction imposed to achieve determinacy of the problem.

Another interesting property of PCA is the fact that the preceding equation (equation 2 in this case) inverted so that the principal components stated as a function of original variables and factor scores (Jackson, 2003). This yields a set of estimates for each of $Z$ principal components:

$$
\begin{gathered}
V_{1 j}=f_{11} a_{1 j}+f_{12} a_{2 j}+\cdots+f_{1 z} a_{z j} \\
\ldots \\
V_{z j}=f_{z 1} a_{1 j}+f_{z 2} a_{2 j}+\ldots+f_{z z} a_{z j}, \ldots \ldots \ldots \ldots \ldots \ldots \ldots \ldots \ldots \ldots \ldots \ldots \ldots \ldots \ldots \ldots \ldots \ldots \ldots \\
j=1 \ldots \ldots \ldots
\end{gathered}
$$

Where the $f$ 's are the factor scores. Following Filmer and Pritchett (2001), the first principal component, expressed in terms of the original (un-normalized) variables is an index for each agro-ecosystem/household of the study areas based on the following expression:

$$
V_{1 j}=f_{11}\left(a_{1 j}^{*}-a_{1}^{*}\right) /\left(s_{1}^{*}\right)+\cdots+f_{1 z}\left(a_{Z j}^{*}-a_{Z}^{*}\right) /\left(s_{Z}^{*}\right)
$$

PCA run for exposure, sensitivity, and adaptive capacity indicators. The loadings from the first principal component used as the weights for the indicators, and vulnerability index for each household is calculated using equation 1.

However, the indexes do not give the absolute measurement (Jackson, 2003); rather the index values give a comparative ranking of a given sampled analysis units. On the other hand, PCA not only performs data reduction to come up with principal components for obtaining indexes, but also accomplishes it in a manner that permits its results to be used in applications of other multivariate statistical methods (e.g., regression analysis) (Raykov and Marcoulides, 2008). Subsequently the relative effects of significant principal components and the detailed impacts of variables/indicators in these principal components on the vulnerability of each agro-ecosystem/household examined through ordered probit regression and other relevant qualitative data analysis techniques. 
Accordingly, ordered probit model applied in households' vulnerability analysis. Following Greene (2003), the reduced form of the ordinal logit model given as

$$
Y_{j}^{*}=X_{j}^{1} \beta+u_{I j}
$$

Where, $\mathrm{Y}$ is the level of vulnerability involving ordered outcome. $\mathrm{Y}=1$, given to households with a high level of vulnerability as observed by the negative value of adaptive capacity minus sensitivity/exposure; $\mathrm{Y}=2$, given to households having adaptive capacity nearly equal to their sensitivity/exposure; and $\mathrm{Y}=3$ given to households having their adaptive capacity exceeding their sensitivity and exposure. $\mathrm{Y}^{*}$ is the given state of vulnerability. The $X_{i j}$, are the explanatory variables determining vulnerability level. $\beta_{s}$, are parameters estimated and $u_{i j}$, is the disturbance term. $\mathrm{Y}^{*}$ is unobserved, but what was observed in this study is

- $\quad \mathrm{Y}=1$ if $\mathrm{Y}^{*} \leq \mu 2$

- $Y=2$ if $\mu 2<\mathrm{Y}^{*} \leq \mu 3$

- $\mathrm{Y}=3$ if $\mu 3<\mathrm{Y}^{*}$

Given the cumulative normal function $\Phi\left(\beta^{\prime} \mathrm{X}\right)$, the probabilities can be shown, thus,

- $\quad$ Prob $[y=1$ or highly vulnerable $]=\Phi\left(-\beta^{\prime} x\right)$,

- $\quad$ Prob $[y=2$ or neutral level of vulnerability $]=\Phi\left(\mu 2-\beta^{\prime} x\right)-\Phi\left(\mu 3-\beta^{\prime} x\right)$,

- $\quad$ Prob $[\mathrm{y}=3$ or less vulnerable $]=1-\Phi\left(\mu 3-\beta^{\prime} \mathrm{x}\right)$

\section{Empirical Model for the Study}

PCA run separately for adaptive capacity, sensitivity, and exposure of households at each agro-ecosystem. The loadings of first PC explaining the majority of the variation in the data set are taken as factor scores. Accordingly, factor scores from the first PC and the normalized values of the corresponding variables employed to construct indices for each vulnerability component of households at each agro-ecosystem. Then, vulnerability index for each household is calculated using equation 1. Finally, the obtained indexes explained using relevant indicators and qualitative findings from key informants, focus group discussion participants, and observations.

$$
\mathbf{A C I}=(\mathrm{DV} * \boldsymbol{Z D} \boldsymbol{V})+(\mathrm{LC} * \boldsymbol{Z} \boldsymbol{L C})+(\mathrm{T} * \boldsymbol{Z T})+(\mathrm{I} * \boldsymbol{Z I})
$$

Where, ACI - Adaptive capacity index

DV - Positively loaded demographic variables factor scores

ZDV- Normalized value of positively loaded demographic variables

LC - Positively loaded livelihood capitals factor scores

ZLC- Normalized value of positively loaded livelihood capitals

$\mathrm{T}$ - Positively loaded access and use of technologies factor scores

ZT - Normalized value of positively loaded access and use of technologies

I - Positively loaded institutions factor scores

ZI - Normalized value of positively loaded institutional factors

$$
\boldsymbol{S I}=(\mathrm{CPRL} * \boldsymbol{Z C P} \boldsymbol{R} \boldsymbol{L})+(\mathrm{LPRD} * \boldsymbol{Z} \boldsymbol{L P} \boldsymbol{R} \boldsymbol{D})+(\mathrm{FS} * \boldsymbol{Z} \boldsymbol{F S})+(\mathrm{WS} * \boldsymbol{Z} \boldsymbol{W} \boldsymbol{S})+(\mathrm{C} * \boldsymbol{Z C})
$$

Where, SI - Sensitivity index

CPRL - Crop production reduction or loss factor scores

ZCPRL - Normalized value of crop production reduction or loss

LPRD - Livestock production reduction or death factor scores

ZLPRD - Normalized value of livestock production reduction or death

FS - Food shortage factor scores

ZFS - Normalized value of food shortage

WS - Water scarcity factor scores

ZWS - Normalized value of water scarcity

$\mathrm{C}-$ Conflict factor scores

$\mathrm{ZC}-$ Normalized value of conflict

Where, EI - Exposure index

$$
\mathbf{E I}=(\mathrm{TIP} * \boldsymbol{Z T I P})+(\mathrm{RFDP} * \boldsymbol{Z} \boldsymbol{R} \boldsymbol{F} \boldsymbol{D P})+(\mathrm{FDO} * \boldsymbol{Z F} \boldsymbol{D O})
$$

TIP - Temperature increase perception factor scores

ZTIP - Normalized value of temperature increase perception

RFDP - Rainfall decrease perception factor scores

ZRFDP - Normalized value of rainfall decrease perception

FDO - Frequency of drought occurrence factor scores

ZFDO - Normalized value of Frequency of drought occurrence

Then,

Where, VI - Vulnerability index

$$
\mathrm{VI}=(\mathrm{ACI})-(\mathrm{SI})-(\mathrm{EI})
$$

ACI - Adaptive capacity index 


\section{SI - Sensitivity index \\ EI - Exposure index}

\section{Data Analysis}

The survey data edited, coded and entered into a computer, and then analyzed using SPSS and STATA soft-wares. Primarily, descriptive analysis is done to present data/information in a manageable and understandable form. Subsequently, inferential analysis performed through principal component analysis model to examine climate change vulnerability of agro-ecosystems. On the other hand, the qualitative data gathered through observations, key informant interviews, and focus group discussions are analyzed using content analysis. Finally, the obtained indexes of different agro-ecosystems explained using relevant indicators and qualitative findings from key informants, focus group discussion participants, and observations.

\section{Description of Model Variables}

The model variables for this study are categorized by exposure, sensitivity, and adaptive capacity (Table 2). The household's adaptive capacity constitutes demographic variables, livelihood strategy, livelihood capitals, access and use of modern technology, and institutions hypothesized to influence households' vulnerability in drought prone areas of northeastern Ethiopia. The sensitivity and exposure constitutes environmental and related factors. Table 1: Vulnerability indicators, description, and anticipated direction in relation to vulnerability of households

\begin{tabular}{|c|c|c|c|c|}
\hline $\begin{array}{l}\text { Vulnerability } \\
\text { sub-component }\end{array}$ & $\begin{array}{c}\text { Vulnerability } \\
\text { indicators } \\
\text { category }\end{array}$ & Vulnerability indicators & Description & $\begin{array}{l}\text { Relationship } \\
\text { with } \\
\text { Vulnerability }\end{array}$ \\
\hline \multirow[t]{3}{*}{ Exposure } & \multirow[t]{3}{*}{$\begin{array}{l}\text { Environmental } \\
\text { factors }\end{array}$} & $\begin{array}{l}\text { Perception of temperature } \\
\text { increase }\end{array}$ & $\begin{array}{l}1 \text { if households perceive increased temperature } \\
\text { and } 0 \text { otherwise }\end{array}$ & + or - \\
\hline & & $\begin{array}{l}\text { Perception of rainfall } \\
\text { decrease }\end{array}$ & $\begin{array}{l}1 \text { if households perceive decreased rainfall and } \\
0 \text { otherwise }\end{array}$ & + or - \\
\hline & & $\begin{array}{l}\text { Drought } \\
\text { frequency }\end{array}$ & 1 if drought occurred yearly and 0 otherwise & + or - \\
\hline \multirow[t]{5}{*}{ Sensitivity } & \multirow{5}{*}{$\begin{array}{l}\text { Environmental } \\
\text { and related } \\
\text { factors }\end{array}$} & $\begin{array}{ll}\text { Crop } & \text { productivity } \\
\text { reduction/loss }\end{array}$ & 1 if households face crop failure and 0 otherwise & + or - \\
\hline & & $\begin{array}{l}\text { Livestock productivity } \\
\text { reduction/death }\end{array}$ & $\begin{array}{l}1 \text { if households encountered livestock death and } \\
0 \text { otherwise }\end{array}$ & + or - \\
\hline & & Water scarcity & $\begin{array}{l}1 \text { if households face water scarcity and } 0 \\
\text { otherwise }\end{array}$ & + or - \\
\hline & & Food shortage & $\begin{array}{l}1 \text { if households face food shortage and } 0 \\
\text { otherwise }\end{array}$ & + or - \\
\hline & & Conflict & 1 if households face conflict and 0 otherwise & + or - \\
\hline \multirow{20}{*}{$\begin{array}{l}\text { Adaptive } \\
\text { capacity }\end{array}$} & \multirow{3}{*}{$\begin{array}{l}\text { Demographic } \\
\text { variables }\end{array}$} & Gender & 1 if a household is male and 0 otherwise & + or - \\
\hline & & Household size & Number of household size & Positive \\
\hline & & Number of dependents & Number of dependents & Positive \\
\hline & \multirow[t]{13}{*}{$\begin{array}{l}\text { Livelihood } \\
\text { capitals }\end{array}$} & Formal education & $\begin{array}{l}1 \text { if a household has formal education and } 0 \\
\text { otherwise }\end{array}$ & Positive \\
\hline & & Adult education & $\begin{array}{l}1 \text { if a household participated in adult education } \\
\text { and } 0 \text { otherwise }\end{array}$ & + or - \\
\hline & & Framing experience & Number of years & Positive \\
\hline & & Access to information & $\begin{array}{l}1 \text { if a household has access to information and } \\
0 \text { otherwise }\end{array}$ & + or - \\
\hline & & Health status & $\begin{array}{l}1 \text { if any household members are not sick and } 0 \\
\text { otherwise }\end{array}$ & + or - \\
\hline & & Social networks & $\begin{array}{l}1 \text { if a household has social networks and } 0 \\
\text { otherwise }\end{array}$ & + or - \\
\hline & & Institutional membership & $\begin{array}{l}1 \text { if a household has institutional membership } \\
\text { and } 0 \text { otherwise }\end{array}$ & + or - \\
\hline & & Land ownership & Land owned in timads ( 4 timads $=1$ hectare $)$ & Positive \\
\hline & & Mobile phone possession & $\begin{array}{l}1 \text { if a household has mobile phone and } 0 \\
\text { otherwise }\end{array}$ & + or - \\
\hline & & Saving & 1 if a household has saving and 0 otherwise & + or - \\
\hline & & Credit taking & 1 if a household has taken credit and 0 otherwise & + or - \\
\hline & & Livestock ownership & Livestock owned in TLUs & Positive \\
\hline & & Non-agricultural income & $\begin{array}{l}1 \text { if a household has non-agricultural income } \\
\text { source and } 0 \text { otherwise }\end{array}$ & + or - \\
\hline & \multirow[t]{2}{*}{$\begin{array}{l}\text { Technological } \\
\text { variables }\end{array}$} & Water harvesting & $\begin{array}{l}1 \text { if a household use water harvesting and } 0 \\
\text { otherwise }\end{array}$ & + or - \\
\hline & & Irrigation & $\begin{array}{l}1 \text { if a household practice irrigation and } 0 \\
\text { otherwise }\end{array}$ & + or - \\
\hline & \multirow[t]{2}{*}{$\begin{array}{l}\text { Institutional } \\
\text { indicators }\end{array}$} & $\begin{array}{l}\text { Agricultural } \\
\text { services }\end{array}$ & $\begin{array}{l}1 \text { if a household has agricultural extension } \\
\text { service and } 0 \text { otherwise }\end{array}$ & + or - \\
\hline & & Market access & $\begin{array}{l}1 \text { if a household has market access and } 0 \\
\text { otherwise }\end{array}$ & + or - \\
\hline
\end{tabular}




\section{RESULTS AND DISCUSSIONS}

\section{Environmental Contexts}

Total annual average temperature has increased by $2.9^{\circ} \mathrm{C}$ in Lalibela station, by $0.35^{\circ} \mathrm{C}$ in Alamata station, and by $1.3^{0} \mathrm{C}$ in Dubti station within 30 years (Figure 2). This shows that temperature is increasing in all of the three stations though the magnitude is different. A study conducted by Assefa (2009) asserted that warming has occurred across Ethiopia, particularly since the 1970s at a variable rate but broadly consistent with wider African and global trends with increasing trend in time $\left(0.37^{\circ} \mathrm{C} /\right.$ decade $)$. On the other hand, IPCC (2014) has indicated that warming in excess of $1{ }^{\circ} \mathrm{C}$ has negative impacts without adaptation. Above $1{ }^{\circ} \mathrm{C}$ temperature increase, is found in the two stations except Alamata station during the last 20-30 years showing that such temperature increase has caused different negative impacts in the study areas. Likewise, key informants and focus group discussion participants from the respective agro-ecosystems have asserted that temperature has increased in their locality during the last 20-30 years.

Figure 2: Total annual average temperature trends of Lalibela, Alamata and Dubti stations from 1980-2010

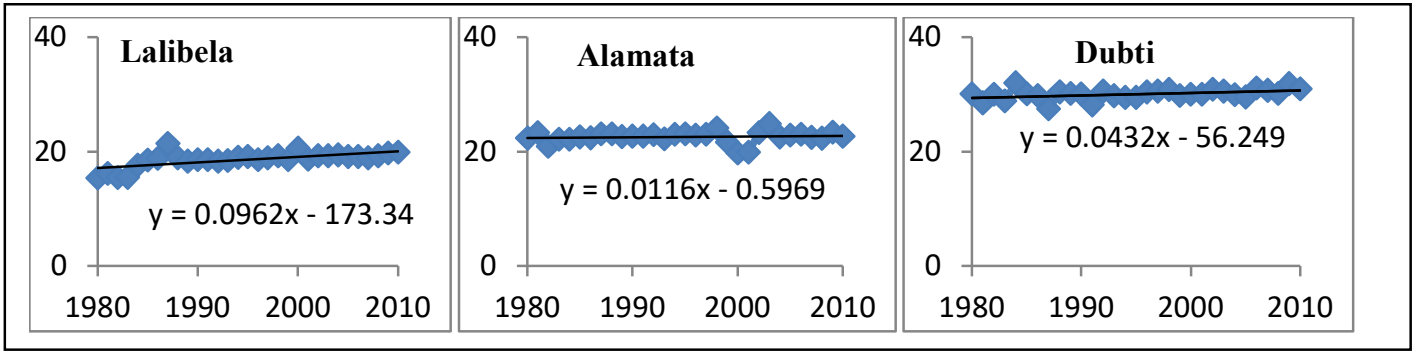

Source: NMA, 2012

On the other hand, annual rainfall has increased by 107, 157 and $10 \mathrm{~mm}$ in Lalibela, Alamata and Dubti stations respectively in 30 years (Figure 3). However, a study conducted by World Bank (2010) has shown that there was drought in most of these periods that have led to livelihood insecurity; and another study by Riche et al. (2009) has indicated that the frequency of drought has increased from every 5-10 years to 1-2 years. The probable reason might be that the amount of rainfall may not be decreased or even it may be increased as indicated in figure 2 , however, what matters is the distribution of the rainfall. In relation to this, a key informant from lowland mixed farming agro-ecosystem has argued that, there is a huge amount of rainfall for some days or sometimes for months; however, it will stop raining at a critical time when the planted crops require rain/water. In line with this, a key informant from the highland mixed farming agro-ecosystem has pointed out that in the past when there was cloud, we were sure that there would be rain. However, these days when we are expecting that there will be rain, there is no rain; and any farm preparations made become worthless. Moreover, he added, the livestock are highly affected by shortage of pasture and water due to lack of rain. Accordingly, most households are suffering from drought and then food insecurity. In relation to this, a previous study conducted by Gebremichael and Kifle (2009) asserted that as there is decrease in rainfall there is decrease in crop and livestock productivity.

Figure 3: Annual rainfall trends of Lalibela, Alamata and Dubti stations from 1980-2010

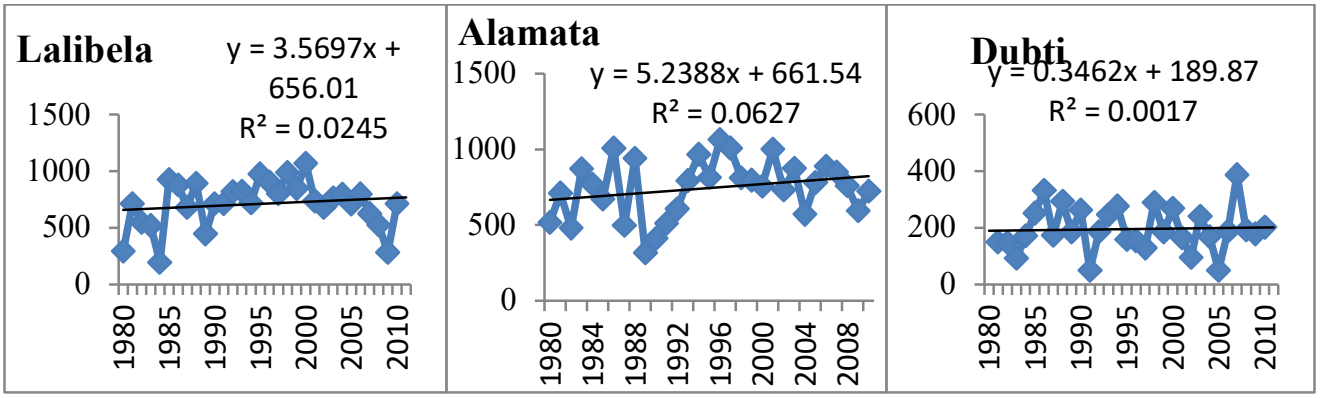

Source: NMA, 2012

Similarly, rainfall anomalies graph of Lalibela, Alamata and Dubti stations from 1980-2010 show that while some years have been characterized by dry conditions resulting in drought and famine like the great famine in 1984, others are characterized by wet conditions (Figure 4). The graphs show that the normalized deviation value of rainfall is below zero in almost half of the last 30 years indicating that there was drought in most of these years. As it was discussed with key informants and participants in the focus group discussion when the frequency of drought increases, the possibility of the local people to fall into livelihood insecurity increases. 
Figure 4: Rainfall Anomalies of Lalibela, Alamata and Dubti stations from 1980-2010

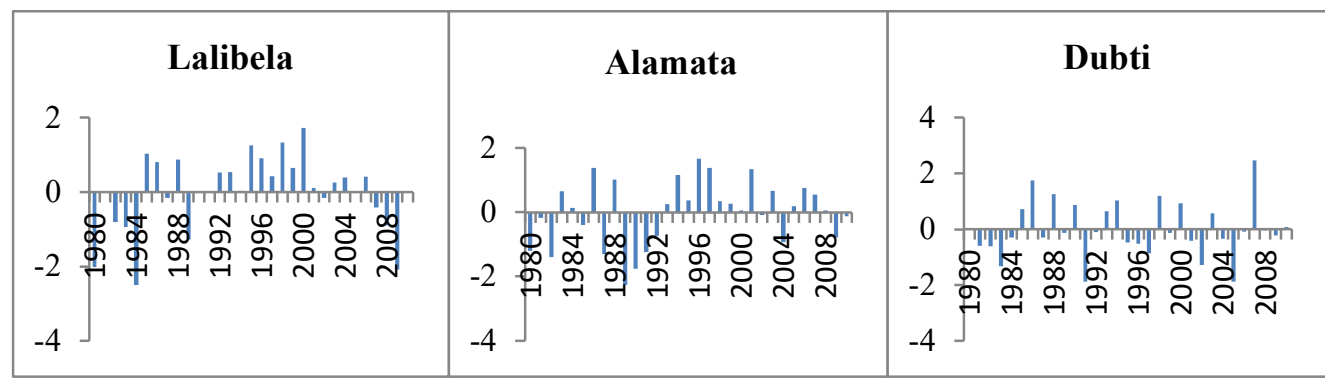

Source: NMA, 2012

\section{Vulnerability Analysis}

In households' vulnerability analysis, the mean and the standard deviation of adaptive capacity, sensitivity, exposure, and vulnerability indexes of households are calculated (Table 3) to set the cut off values for vulnerability categories. Based on these mean and standard deviation, adaptive capacity, sensitivity, exposure, and vulnerability categories of households established for each agro-ecosystem. Accordingly, less adaptive, less sensitive, less exposed and highly vulnerable categories are less than or equal to minus one standard deviation from the mean. Moreover, moderately adaptive, sensitive, exposed and vulnerable categories are between plus or minus one standard deviation from the mean. Furthermore, highly adaptive, highly sensitive, highly exposed and less vulnerable categories are greater than or equal to plus one standard deviation from the mean.

Table 3: Descriptive Statistics of Household Indexes

\begin{tabular}{lccccc}
\hline & $\mathrm{N}$ & Minimum & Maximum & Mean & Std. Deviation \\
\hline Adaptive capacity index & 426 & -3.97 & 4.08 & -0.0171 & 1.74404 \\
Sensitivity index & 426 & -2.44 & 1.74 & 0.0869 & 1.34990 \\
Exposure index & 426 & -2.26 & 1.50 & 0.0606 & 1.37297 \\
Vulnerability index & 426 & -5.39 & 7.43 & -0.1645 & 2.36761 \\
\hline
\end{tabular}

Source: Field Survey, 2014

\section{Adaptive Capacity of Households}

Table 4 shows that 16.4, 12.8, 47.9 and 3 percent of households in highland mixed farming, lowland mixed farming, agro-pastoral, and pastoral agro-ecosystems respectively are less adaptive. Moreover, 68.5, 67.8, 29.2 and 87.9 percent of households in highland mixed farming, lowland mixed farming, agro-pastoral, and pastoral agro-ecosystems respectively are moderately adaptive (Table 4). Furthermore, 15.2, 19.4, 22.9 and 9.1 percent of households in highland mixed farming, lowland mixed farming, agro-pastoral, and pastoral agro-ecosystems respectively are highly adaptive (Table 4 ).

Table 4: Classification of households by the range of their adaptive capacity index

\begin{tabular}{|c|c|c|c|c|c|}
\hline \multirow{2}{*}{$\begin{array}{l}\text { Adaptive } \\
\text { category }\end{array}$} & \multirow{2}{*}{$\begin{array}{c}\text { Adaptive } \\
\text { capacity index }\end{array}$} & \multicolumn{4}{|c|}{ Percentage of Households in Agro-ecosystems } \\
\hline & & $\begin{array}{l}\text { Highland Mixed } \\
\text { Farming }\end{array}$ & $\begin{array}{l}\text { Lowland Mixed } \\
\text { Farming }\end{array}$ & Agro-pastoral & Pastoral \\
\hline Less adaptive & -4.0 to -1.761 & 16.4 & 12.8 & 47.9 & 3.0 \\
\hline Moderately adaptive & -1.76 to 1.73 & 68.5 & 67.8 & 29.2 & 87.9 \\
\hline Highly adaptive & 1.731 to 5.0 & 15.2 & 19.4 & 22.9 & 9.1 \\
\hline Total & & 100 & 100 & 100 & 100 \\
\hline
\end{tabular}

Source: Field Survey, 2014

This shows that less than a quarter of households are highly adaptive in all agro-ecosystems. Moreover, the majority of the households in agro-pastoral agro-ecosystem are less adaptive. Similarly, some key informants from lowland agro-pastoral and pastoral agro-ecosystems consider themselves as less adaptive as they are entirely dependent on livestock production. On the contrary, some focus group discussion participants from the same agroecosystems argue that it is possible to earn the whole income gained from several plots of uncertain agricultural production from one camel as a camel worth currently about 25 thousand Ethiopian Birr. This is in line with, a study conducted by PCDP (2005) showing that the households gains low from crop production due to low yield caused by unreliable rainfall, for instance, less than one quintal of maize and sorghum from one hectare of land during 2004 in Fokisa kebele at Golina district. Hence, they added, households in agro-pastoral and pastoral agroecosystems are better adaptive as a camel is productive even in erratic rainfall, which would not be suitable for crop production. 


\section{Sensitivity of Households}

As can be seen from Table 5, 20.6, 23.9, 29.2 and 27.3 percent of households in highland mixed farming, lowland mixed farming, agro-pastoral, and pastoral agro-ecosystems respectively are less sensitive. Table 5 also shows that 49.7, 52.2, 52.1 and 51.5 percent of households in highland mixed farming, lowland mixed farming, agro-pastoral, and pastoral agro-ecosystems respectively are moderately sensitive. Moreover, 29.7, 23.9, 18.8 and 21.2 percent of households in highland mixed farming, lowland mixed farming, agro-pastoral, and pastoral agro-ecosystems respectively are highly sensitive (Table 5). Table 5: Classification of households by the range of their sensitivity index

\begin{tabular}{lccccc}
\hline Sensitivity category & Sensitivity index & \multicolumn{3}{c}{ Percentage of Households in Agro-ecosystems } \\
\cline { 3 - 6 } & & $\begin{array}{c}\text { Highland Mixed } \\
\text { Farming }\end{array}$ & $\begin{array}{c}\text { Lowland } \\
\text { Mixed } \\
\text { Farming }\end{array}$ & Agro-pastoral & Pastoral \\
Less sensitive & -3.0 to -1.261 & 20.6 & 23.9 & 29.2 & 27.3 \\
Moderately sensitive & -1.26 to 1.44 & 49.7 & 52.2 & 52.1 & 51.5 \\
Highly sensitive & 1.441 to 2.0 & 29.7 & 23.9 & 18.8 & 21.2 \\
& & 100 & 100 & 100 & 100 \\
\hline
\end{tabular}

Source: Field Survey, 2014

This implies that the majority of the households in all agro-ecosystem are moderately sensitive. However, less than one-third of households are less sensitive in all agro-ecosystems. In line with this, key informants and focus group discussion participants have argued that households in the study locality are highly vulnerable to climate change impacts especially to drought. As it was also observed, households in the study locality are highly affected by climate change impacts particularly El Nino induced drought occurred currently in northeastern and other parts of Ethiopia. A study conducted by Piya et al. (2012) asserted that among the weights for sensitivity indicators, impacts due to natural disasters have influenced more to the overall sensitivity index. More specifically, because of higher occurrences of drought over a decade, the study households were highly vulnerable to climate change impacts.

\section{Exposure of Households}

Table 6 shows that 21.2, 20, 31.3 and 30.3 percents of households in highland mixed farming, lowland mixed farming, agro-pastoral and pastoral agro-ecosystems are less exposed respectively. Moreover, 33.9, 80, 68.8 and 69.7 percent of households in highland mixed farming, lowland mixed farming, agro-pastoral, and pastoral agroecosystems respectively are moderately exposed (Table 6). Furthermore, it is only in highland mixed farming agroecosystem that 44.8 percent of households are highly exposed while none of households in lowland mixed farming, agro-pastoral and pastoral agro-ecosystems are highly exposed (Table 6).

Table 6: Classification of households by the range of their exposure index

\begin{tabular}{lccccc}
\hline \multirow{2}{*}{ Exposure category } & & \multicolumn{3}{c}{ Percentage of Households in Agro-ecosystems } \\
\cline { 3 - 6 } & $\begin{array}{c}\text { Exposure } \\
\text { index }\end{array}$ & $\begin{array}{c}\text { Highland Mixed } \\
\text { Farming }\end{array}$ & $\begin{array}{c}\text { Lowland Mixed } \\
\text { Farming }\end{array}$ & Agro-pastoral & Pastoral \\
Less exposed & -3.0 to -1.311 & 21.2 & 20.0 & 31.3 & 30.3 \\
Moderately exposed & -1.31 to 1.43 & 33.9 & 80.0 & 68.8 & 69.7 \\
Highly exposed & 1.431 to 2.0 & 44.8 & 0 & 0 & 0 \\
& & 100 & 100 & 100 & 100 \\
\hline
\end{tabular}

Source: Field Survey, 2014

This indicates that the majority of the households in most agro-ecosystems are moderately exposed except highland mixed farming agro-ecosystem. While none of the households in lowland mixed farming, agro-pastoral and pastoral agro-ecosystems is highly exposed, the majority of households in highland mixed farming agroecosystem are highly exposed. This might be due to the fact that households in lowland mixed farming, agropastoral and pastoral agro-ecosystems are better in adapting to climate change impacts/stresses. A study conducted by Tesso et al. (2012) confirmed this, arguing that contrary to the expectations, the lowland area was not highly exposed to climate change extremes when compared to the midland and highland areas/agro-ecologies as they have experiences of changing/stressful climatic conditions.

\section{Vulnerability of Households}

Table 7 shows that 24.8, 11.1, 20.8 and 9.1 percent of households in highland mixed farming, lowland mixed farming, agro-pastoral, and pastoral agro-ecosystems respectively are highly vulnerable. Moreover, 58.2, 71.1, 72.9 and 87.9 percent of households in highland mixed farming, lowland mixed farming, agro-pastoral, and pastoral agro-ecosystems respectively are moderately vulnerable (Table 7). Furthermore, 17, 17.8, 6.3 and 3 percent of households in highland mixed farming, lowland mixed farming, agro-pastoral, and pastoral agro- 
ecosystems respectively are less vulnerable (Table 7). Similarly, Opiyo et al. (2014) has classified households into three categories using the vulnerability index. Thus, less vulnerable households are those in a vulnerable situation but can still cope; moderately vulnerable households are those that need urgent but temporary assistance during shock and stresses; and highly vulnerable households are those at a point of no return (Opiyo et al., 2014) with the majority [44 percent] of households fall within the moderately vulnerable category having an index from -0.9 to 1.0; the less vulnerable households had an index of 1.1 to 3.0 constituting 29 percent; and the highly vulnerable households had an index of -1.0 to -3.0 comprising 27 percent (Opiyo et al., 2014). Table 7: Classification of households by the range of their vulnerability index

\begin{tabular}{lccccc}
\hline Vulnerability category & $\begin{array}{c}\text { Vulnerability } \\
\text { index }\end{array}$ & \multicolumn{4}{c}{ Percentage of Households in Agro-ecosystems } \\
\cline { 3 - 6 } & & $\begin{array}{c}\text { Highland Mixed } \\
\text { Farming }\end{array}$ & $\begin{array}{c}\text { Lowland Mixed } \\
\text { Farming }\end{array}$ & Agro-pastoral & Pastoral \\
Highly vulnerable & -6.0 to -2.531 & 24.8 & 11.1 & 20.8 & 9.1 \\
Moderately vulnerable & -2.53 to 2.2 & 58.2 & 71.1 & 72.9 & 87.9 \\
Less vulnerable & 2.21 to 8.0 & 17.0 & 17.8 & 6.3 & 3.0 \\
\multicolumn{1}{c}{ Total } & & 100 & 100 & 100 & 100 \\
\hline
\end{tabular}

Source: Field Survey, 2014

Likewise, the results of this study indicate that the majority of the households in all agro-ecosystems are moderately vulnerable. Moreover, it is only less than one-fifth of the households are less vulnerable in all agroecosystems. Similarly, a key informant from the pastoralist agro-ecosystem has indicated that most of the households face food shortage throughout the year, as they are vulnerable to drought. Furthermore, almost all informants and participants have considered drought as one of the most frequent hazards in northeastern Ethiopia making households highly vulnerable. This argument confirms Deressa's (2010) assertion about the vulnerability of northeastern Ethiopia particularly in Afar and Tigray regions. Evidence also shows that especially pastoralists are constrained by unpredictable and unstable climatic conditions leading to frequent calamities (conflict and drought), food insecurity, and lack of adequate social services and institutions (FDRE, 2008). Moreover, previous studies in the region like Gebremichael and Kifle (2009) confirmed that it is becoming increasingly difficult for households to bounce back from ever-changing, inconsistent weather affecting their livelihoods, and many have been forced to pursue other livelihoods strategies that only increase the cycle of vulnerability such as selling of fuel-wood and charcoal.

\section{Determinants of Households Vulnerability}

Ordered probit regression model is done to determine variables influencing a household's vulnerability categories in highland mixed farming agro-ecosystem (Table 8). The Chi-squared statistic is statistically significant $[\chi(28)$ $=189.57, p=000$ ] at less than 1 percent significant level. While 28 variables were hypothesized to be correlated with vulnerability, ordered probit regression model result confirmed that 12 factors were statistically significant at $\mathrm{p}<0.1, \mathrm{p}<0.05$ and $\mathrm{p}<0.001$ in influencing highly, moderately, and less vulnerable group of households. Similarly, ordered probit regression model is done for all the single predictors' variables influencing a household's vulnerability in lowland mixed farming agro-ecosystem (Table 8). The Chi-squared statistic is statistically significant $[\chi(28)=274.81, p=000]$ at less than 1 percent significant level. Out of 28 variables which were hypothesized to be correlated with vulnerability, ordered regression model result confirmed that 9 factors were significant (at $\mathrm{p}<0.1, \mathrm{p}<0.05$ and $\mathrm{p}<0.001$ ) in influencing highly, moderately, and less vulnerable group of households. Ordered probit regression model is also done for all the single predictors' variables influencing a household's vulnerability in agro-pastoral agro-ecosystem (Table 8). The Chi-squared statistic is statistically significant $[\chi(26)=121.04, p=000]$ at less than 1 percent significant level. While 26 variables were hypothesized to be correlated with vulnerability, ordinal regression model result confirmed that 13 factors were significant (at $\mathrm{p}$ $<0.1, \mathrm{p}<0.05$ and $\mathrm{p}<0.001)$ in influencing highly, moderately, and less vulnerable group of households. Moreover, ordered probit regression model done for all the single predictors' variables influencing a household's vulnerability in pastoral agro-ecosystem (Table 8 ). The Chi-squared statistic is statistically significant $[\chi(24)$ $=106.38, p=000$ ] at less than 1 percent significant level. While 24 variables were hypothesized to be correlated with vulnerability, ordinal regression model result confirmed that 13 factors were significant (at $p<0.1, p<0.05$ and $\mathrm{p}<0.05$ and $\mathrm{p}<0.001$ ) in influencing highly, moderately, and less vulnerable group of households. Accordingly, some of the significant variables of the four agro-ecosystems are discussed as follows:

\section{Formal Education}

Formal education decreases significantly the probability of vulnerability of highly, moderately and less vulnerable group of households by $72.2,64$ and 86.8 percent respectively in agro-pastoral agro-ecosystems (Table 8). Key informants and focus group discussion participants have also argued that attending formal education improves skills to increase productivity and improve livelihoods. Similarly, a previously conducted study has indicated that a good level of education increases available livelihood options and enhance adaptive capacity of households 
(Dulal et al., 2010). Moreover, Tesso et al. (2012) has asserted household heads with higher level of education have better level of planning, access and understanding of early warning information, better decision-making skills during natural shocks, alter agricultural operation, and adopt extension packages. Thus, education is one of the key factors in building the resilience level of households to climate change impacts.

\section{Access to Information}

Access to information decreases significantly the probability of vulnerability of less vulnerable group of households by 63.6 percent in agro-pastoral agro-ecosystem (Table 8). In line with this, key informants and focus group discussion participants argued that households with access to information are better in adapting to climate change impacts. A study conducted by Kansiime et al. (2014) asserted that access to weather information guides farmers/pastoralists in making adaptation decisions. This might be because of Dagu (the traditional information exchange mechanism of pastoralists) in which pastoralists exchange information to adapt to climate change especially during drought.

\section{Social Networks}

Social networks (relations with relatives, friends and agricultural extension workers) decrease significantly the probability of vulnerability of highly, moderately and less vulnerable group of households by $51.4,44.5$ and 40.9 percent respectively in highland mixed farming agro-ecosystem (Table 8). This shows that when households form strong relationships with their relatives, friends and agricultural extension workers, they can get different kinds of inputs in the form of information, skills and knowledge to improve their livelihoods and in turn become less vulnerable to climate change. In line with this, Balew et al. (2014) found that since social network improve the capacity of smallholder farmers to adapt to climate change impacts they are less vulnerable.

\section{Institutional Membership}

Institutional membership decreases significantly the probability of vulnerability of highly and less vulnerable group of households by 50.5 and 51.8 percent respectively in lowland mixed farming agro-ecosystem (Table 8). In connection to this, Balew et al. (2014) asserted that farmers who are members of any farmers group found in the village have 11 percent higher probability of adapting to climate change using various method of adaptation and in turn decreasing their vulnerability. This might be because of institutional membership like credit and saving institution or any association, which offers credit and labor; gives a chance of engaging in non-agricultural income generating activities and exchanging information about the better type of livestock and crops in resisting drought, productivity and better market prices which are very important things in reducing vulnerability.

\section{Land Ownership}

Land ownership decreases significantly the probability of vulnerability of highly vulnerable group of households by 26.7 percent in agro-pastoral agro-ecosystem (Table 8 ). The possible reason might be when households have large farm size they are more likely to have better access to fodder especially from crop residue which in turn makes them to change their livestock based on their productivity and resisting ability to drought.

\section{Mobile Phone Possession}

Possession of mobile phone decreases significantly the probability of vulnerability of moderately and less vulnerable group of households by 63 and 63.5 percent respectively in pastoral agro-ecosystem (Table 8). As it was observed and confirmed by key informants the poor households who have mobile are not as such benefited from it except expenditure. Key informants and focus group discussion participants have also argued that usually the better off households have mobile phone and these households are less vulnerable since they could be able to get early warning information easily either through radio or telephone.

\section{Saving}

Saving decreases significantly the probability of vulnerability of highly and moderately vulnerable group of households by 21.7 and 21.3 percent respectively in highland mixed farming agro-ecosystem (Table 8). Similarly, saving decreases significantly the probability of vulnerability of highly and moderately vulnerable group of households by 22.1 and 18.3 percent respectively in pastoral agro-ecosystem (Table 8 ). This is because when households save some amount of money, they are insuring themselves to use that money when they face certain problems like drought. Moreover, after saving for some time they can use that money to start any non-agricultural income generating activity to diversify their livelihood strategies, which in turn decreases their vulnerability to climate change impacts. However, key informants and focus group discussion participants have argued that the poor usually have no saving as they lead a subsistence life. Nevertheless, they added, when they save any amount, it has a significant role in improving their livelihoods. 


\section{Taking Credit}

As can be seen from Table 8 , taking credit decreases significantly the probability of vulnerability of highly, moderately and less vulnerable group of households by $40.5,36.1$ and 27.9 percent respectively in highland mixed farming agro-ecosystem. Similarly, taking credit decreases significantly the probability of vulnerability of highly, moderately and less vulnerable group of households by $41.8,38.8$ and 41.2 percent in lowland mixed farming agro-ecosystem (Table 8). As it was observed and asserted by key informants and focus group discussion participants, when the poor took credit they do have a great commitment to accomplish their income generating activities according to the prepared business plan though they often suffer from loss as they use the money for food consumption. However, there are some inconsistencies when credit giving institutions offer credits to households. In line with this a key informant from lowland mixed farming agro-ecosystem has argued that there are two types of credit offerings in their locality: credit offered through household asset building program (HABP) for households who are supported by safety net program, and credit offered for households who are not supported by safety net program. He added, if unfortunately the livestock purchased by the credit is dead due to some diseases, households who are under safety net program forced to pay the money back as they are considered they did it deliberately while those who are not supported by safety net program are exempted. A previous study, Tesso et al. (2012) has also indicated that one of the most challenging factors is access to cash needs in times of crises; and the available micro finances institutions are not as such willing to advance loan during crises, which forces farmers to borrow from local lenders at exorbitantly high interest rates.

\section{Livestock Ownership}

Livestock ownership decreases significantly the probability of vulnerability of highly, moderately and less vulnerable group of households by 14.1, 13.8 and 10.2 percent respectively in highland mixed farming agroecosystem (Table 8). Bazezew et al. (2013) also found that a unit increase in livestock ownership (in TLU) increases annual household income by a factor of 0.33 that lifts households' capacity to respond to climate change impacts and the possibility of being vulnerable.

\section{Water Harvesting}

Water harvesting decreases significantly the probability of vulnerability of highly and moderately vulnerable group of households by 80.4 and 46.1 percent respectively in agro-pastoral agro-ecosystem (Table 8 ). Moreover, water harvesting decreases significantly the probability of vulnerability of highly and less vulnerable group of households by 47 and 27.2 percent respectively in pastoral agro-ecosystem (Table 8). Similarly, Bewket (2009) pointed out that rainwater harvesting and buffering at times of rainfall scarcity through the application of supplemental or protective irrigation might be a good option to protect loss of crop yields, or even complete crop failure which makes households less vulnerable to such climate change impacts.

\section{Practice of Irrigation}

Table 8 also shows that practicing irrigation decreases significantly the probability of vulnerability of highly vulnerable group of households by 33.2 percent in highland mixed farming agro-ecosystem. Similarly, practicing irrigation decreases significantly the probability of vulnerability of highly, moderately and less vulnerable group of households by $36.5,19$ and 36.2 percent respectively in lowland mixed farming agro-ecosystem (Table 8). Irrigation also decreases significantly the probability of vulnerability of highly, moderately and less vulnerable group of households by 98.2, 67.6 and 96.7 percent respectively in agro-pastoral agro-ecosystem (Table 8). Similarly, key informants have argued that households who have access to irrigation are less vulnerable. However, some key informants and focus group discussion participants have also argued that as the better off households usually have access for irrigation water, they use water to irrigate cash crops like onion, and if due to some diseases or other problems faced crop failure they become more vulnerable than the current highly vulnerable group of households. Previously conducted studies Hadgu et al. (2015), Mengistu (2011) and Deressa et al. (2009) have also indicated that farm households who practice irrigation had improved their livelihoods significantly.

\section{Agricultural Extension}

Agricultural extension service decreases significantly the probability of vulnerability of highly, moderately and less vulnerable group of households by $61.7,59$ and 53.8 percent respectively in highland mixed farming agroecosystem (Table 8). Similarly, agricultural extension service decreases significantly the probability of vulnerability of highly, moderately and less vulnerable group of households by $14.7,15$ and 15.1 percent respectively in lowland mixed farming agro-ecosystem (Table 8). Moreover, agricultural extension service decreases significantly the probability of vulnerability of highly, moderately and less vulnerable group of households by 54.6, 23.3 and 59.7 percent respectively in agro-pastoral agro-ecosystem (Table 8). This might be because those households who obtained extension services are better productive and food secure. However, key informants and focus group discussion participants have argued that it is the better off households have better 
access for extension services, and the concerned organs should monitor the services provided by the agricultural extension workers to equally serve the households who are in need of the services.

\section{Market Access}

Market access decreases significantly the probability of vulnerability of highly, moderately and less vulnerable group of households by $61,51.4$ and 74.5 percent respectively in agro-pastoral agro-ecosystem (Table 8). Market access also decreases significantly the probability of vulnerability of highly and less vulnerable group of households by 77 and 45.6 percent respectively in pastoral agro-ecosystem (Table 8). Key informants and focus group discussion participants also pointed out those households who have access to market in their vicinity are less vulnerable to climate change impacts. Similarly, Tesso et al. (2012) stated that access to market or being proximity to market is an important measurement in climate change to bounce back or even to adapt to the changing condition.

\section{Perception of Temperature Increase}

Perceiving increase in temperature decreases significantly the probability of vulnerability of moderately and less vulnerable group of households by 18.6 and 10.1 percent respectively in highland mixed farming agro-ecosystem (Table 8). Similarly, perceiving increase in temperature decreases significantly the probability of vulnerability of less vulnerable group of households by 50.2 percent in agro-pastoral agro-ecosystem (Table 8). Moreover, perceiving increase in temperature decreases significantly the probability of vulnerability of moderately vulnerable group of households by 32 percent in pastoral agro-ecosystem (Table 8 ). This would be due the fact that when the highly vulnerable groups of households perceive temperature change, they engage into different activities like seasonal migration. This could make their left behind family members more vulnerable. This might be also related to the fact that the better off households have more chance to perceive temperature change, as they would have some electronic media like radio and television in addition to mobile to access early warning and other climate change related information to take action timely.

Table 8: Marginal effects of ordered probit regression model for determining factors of households' vulnerability categories by agro -ecosystem

\begin{tabular}{|c|c|c|c|c|c|c|c|c|c|c|c|c|}
\hline \multirow[t]{3}{*}{ Vulnerability indicators } & \multicolumn{12}{|c|}{ Marginal effects } \\
\hline & $\mathrm{Hig}$ & hland mixed f: & arming & \multicolumn{3}{|c|}{ Lowland mixed farming } & \multicolumn{3}{|c|}{ Agro-pastoral } & \multicolumn{3}{|c|}{ Pastoral } \\
\hline & $\begin{array}{c}\text { Highly } \\
\text { vulnerable }\end{array}$ & $\begin{array}{c}\text { Moderately } \\
\text { vulnerable }\end{array}$ & $\begin{array}{c}\text { Less } \\
\text { vulnerable }\end{array}$ & $\begin{array}{c}\text { Highly } \\
\text { vulnerable }\end{array}$ & $\begin{array}{c}\text { Moderately } \\
\text { vulnerable }\end{array}$ & $\begin{array}{c}\text { Less } \\
\text { vulnerable }\end{array}$ & $\begin{array}{c}\text { Highly } \\
\text { vulnerable }\end{array}$ & $\begin{array}{c}\text { Moderately } \\
\text { vulnerable }\end{array}$ & $\begin{array}{c}\text { Less } \\
\text { vulnerable }\end{array}$ & $\begin{array}{c}\text { Highly } \\
\text { vulnerable }\end{array}$ & $\begin{array}{l}\text { Moderately } \\
\text { vulnerable } \\
\end{array}$ & $\begin{array}{c}\text { Less } \\
\text { vulnerable }\end{array}$ \\
\hline $\begin{array}{l}\text { Household head Gender: } \\
\text { male headed }\end{array}$ & -0.159 & -0.108 & 0.085 & 0.004 & -0.007 & -0.010 & -0.222 & 0.172 & -0.284 & -0.175 & $0.400^{*}$ & 0.089 \\
\hline Household size & 0.033 & 0.034 & -0.025 & -0.039 & -0.028 & -0.036 & -0.027 & 0.019 & -0.015 & 0.009 & 0.161 & -0.005 \\
\hline Number of dependents & $0.108^{*}$ & $0.097 *$ & 0.072 & -0.016 & -0.005 & -0.019 & -0.042 & 0.029 & 0.012 & $0.231^{*}$ & -0.090 & $0.137^{*}$ \\
\hline $\begin{array}{l}\text { Formal education: attending } \\
\text { formal education }\end{array}$ & 0.256 & $-0.260^{*}$ & -0.211 & -0.057 & 0.091 & 0.113 & $-0.722 * *$ & $-0.640^{* *}$ & $-0.868 * * *$ & -0.075 & -0.153 & 0.056 \\
\hline $\begin{array}{l}\text { Adult } \\
\begin{array}{l}\text { participating in } \\
\text { education }\end{array}\end{array}$ & 0.084 & 0.088 & -0.068 & -0.083 & 0.120 & 0.149 & 0.041 & -0.029 & 0.047 & 0.155 & -0.052 & -0.069 \\
\hline $\begin{array}{l}\text { Household head farming } \\
\text { experience in years }\end{array}$ & -0.001 & -0.003 & 0.002 & $-0.009 * *$ & $-0.006 *$ & -0.008 & $-0.023 * *$ & $-0.016 *$ & 0.016 & $-0.040^{*}$ & -0.027 & $-0.024 *$ \\
\hline $\begin{array}{l}\text { Access to information: have } \\
\text { access to information }\end{array}$ & -0.010 & -0.009 & 0.006 & $-0.138^{*}$ & $-0.096^{*}$ & $-0.130^{*}$ & -0.411 & 0.007 & $-0.636^{* *}$ & 0.013 & -0.197 & -0.007 \\
\hline $\begin{array}{l}\text { Health status: no household } \\
\text { members sickness in survey } \\
\text { year }\end{array}$ & -0.212 & -0.182 & 0.144 & 0.074 & -0.001 & -0.015 & -0.207 & 0.113 & 0.150 & $-0.337 * *$ & 0.017 & $-0.283^{*}$ \\
\hline $\begin{array}{l}\text { Social networks: have social } \\
\text { networks }\end{array}$ & $-0.514^{* *}$ & $-0.445^{* *}$ & -0.409 ** & -0.191 & -0.389 & -0.181 & -0.204 & 0.164 & -0.116 & -0.263 & 0.095 & 0.100 \\
\hline $\begin{array}{lr}\begin{array}{l}\text { Institutional } \\
\text { have }\end{array} & \begin{array}{r}\text { membership: } \\
\text { institutional }\end{array} \\
\text { membership } & \end{array}$ & -0.140 & -0.141 & 0.120 & $-0.505 * *$ & -0.251 & $-0.518^{* *}$ & 0.098 & -0.061 & 0.057 & 0.050 & -0.086 & -0.031 \\
\hline $\begin{array}{l}\text { Land ownership in } \\
\text { timads**** }\end{array}$ & 0.058 & 0.077 & -0.057 & $-0.037 *$ & -0.024 & -0.036 & $-0.267^{* *}$ & $-0.187^{* *}$ & -0.196 & & & \\
\hline $\begin{array}{l}\text { Mobile phone possession: } \\
\text { have mobile phone }\end{array}$ & 0.159 & -0.138 & -0.021 & 0.032 & -0.016 & 0.033 & -0.131 & 0.082 & -0.215 & -0.005 & $-0.630^{* *}$ & $-0.635^{* *}$ \\
\hline Saving: have saving & $-0.217^{* * *}$ & $-0.213 * * *$ & -0.085 & -0.084 & -0.090 & -0.081 & 0.042 & -0.031 & 0.027 & $-0.222^{* *}$ & $-0.183^{* *}$ & 0.347 \\
\hline $\begin{array}{l}\text { Credit taking: has taken } \\
\text { credit }\end{array}$ & $-0.405^{* * *}$ & $-0.361^{* * *}$ & $-0.279^{* * * *}$ & $-0.418^{* * *}$ & $-0.388^{* * * *}$ & $-0.412 * * *$ & & & & & & \\
\hline $\begin{array}{l}\text { Livestock ownership in TLUs } \\
* * * * * *\end{array}$ & $-0.141^{* *}$ & $-0.138^{* *}$ & $-0.102^{* *}$ & $-0.026^{*}$ & -0.016 & -0.027 & 0.040 & -0.028 & 0.044 & 0.012 & $-0.024 * *$ & -0.007 \\
\hline $\begin{array}{l}\text { Non-agricultural income: } \\
\text { have non-agricultural income }\end{array}$ & 0.024 & 0.019 & -0.014 & 0.012 & 0.018 & 0.023 & 0.323 & -0.278 & $-0.618^{*}$ & 0.637 & 0.086 & $-0.162^{* *}$ \\
\hline $\begin{array}{l}\text { Water harvesting: harvesting } \\
\text { water }\end{array}$ & 0.098 & 0.085 & -0.065 & 0.081 & 0.054 & 0.076 & $-0.804^{* *}$ & $-0.461^{* * *}$ & 0.653 & $-0.470^{* * *}$ & 0.147 & $-0.272^{* * *}$ \\
\hline $\begin{array}{l}\text { Irrigation: } \\
\text { irrigation }\end{array}$ & $-0.332 * * *$ & -0.323 & 0.020 & $-0.365 * * *$ & $-0.190^{* *}$ & $-0.362^{* * * *}$ & $-0.982 * * *$ & $-0.676^{* * * *}$ & $-0.967 * * *$ & & & \\
\hline $\begin{array}{l}\text { Agricultural extension } \\
\text { services: have got services }\end{array}$ & $-0.617^{* *}$ & $-0.590 * *$ & $-0.538^{* *}$ & $-0.147 *$ & $-0.150^{*}$ & $-0.151^{*}$ & $-0.546 * * *$ & $-0.233^{* *}$ & $-0.597 * * *$ & -0.136 & -0.005 & 0.080 \\
\hline $\begin{array}{l}\text { Market access: have market } \\
\text { access }\end{array}$ & 0.037 & 0.022 & -0.016 & -0.380 & -0.474 & -0.478 & $-0.610^{* * *}$ & $-0.514^{* *}$ & $-0.745 * * *$ & $-0.770^{* * * *}$ & 0.124 & $-0.456^{* *}$ \\
\hline $\begin{array}{lcr}\text { Perception } & \text { to temp.: } \\
\text { perceiving } & \text { temperature } \\
\text { increase } & \text { teats }\end{array}$ & -0.192 & $-0.186 * *$ & $-0.101^{* *}$ & -0.012 & 0.008 & -0.021 & 0.324 & -0.106 & $-0.502^{* *}$ & 0.257 & $-0.320^{* *}$ & -0.247 \\
\hline $\begin{array}{l}\text { Perception to rainfall: } \\
\text { perceiving rainfall decrease }\end{array}$ & -0.254 & $-0.233^{*}$ & 0.180 & 0.059 & 0.016 & 0.058 & -0.331 & 0.258 & $-0.743^{*}$ & -0.423 & -0.230 & 0.179 \\
\hline $\begin{array}{l}\text { Drought occurrence } \\
\text { frequency: occurring every } \\
\text { year }\end{array}$ & $0.334^{* * *}$ & $0.325 * *$ & $0.223^{* *}$ & 0.012 & -0.043 & 0.002 & 0.054 & -0.037 & 0.153 & $0.209^{*}$ & 0.109 & -0.152 \\
\hline $\begin{array}{l}\text { Crop } \\
\text { reduction/loss: facing crop } \\
\text { failure }\end{array}$ & 0.114 & $0.128^{*}$ & 0.072 & $0.130 * *$ & $0.097^{*}$ & $0.138^{* *}$ & & & & & & \\
\hline $\begin{array}{l}\begin{array}{l}\text { Livestock } \\
\text { reduction/death: } \\
\text { livestock death }\end{array} \\
\begin{array}{l}\text { facing } \\
\text { factity }\end{array} \\
\end{array}$ & $0.028^{*}$ & 0.019 & -0.014 & -0.081 & -0.040 & -0.084 & $0.568 * * *$ & $0.471 * * *$ & $0.545^{* * * *}$ & $0.685^{* * *}$ & $0.414 * *$ & $0.680^{*}$ \\
\hline
\end{tabular}




\begin{tabular}{|c|c|c|c|c|c|c|c|c|c|c|c|c|}
\hline \multirow[t]{3}{*}{ Vulnerability indicators } & \multicolumn{12}{|c|}{ Marginal effects } \\
\hline & $\mathrm{Hig}$ & land mixed $f$ & arming & Low & land mixed $f$ & rming & & Agro-pastor: & & & Pastoral & \\
\hline & $\begin{array}{c}\text { Highly } \\
\text { vulnerable }\end{array}$ & $\begin{array}{l}\text { Moderately } \\
\text { vulnerable }\end{array}$ & $\begin{array}{c}\text { Less } \\
\text { vulnerable }\end{array}$ & $\begin{array}{l}\text { Highly } \\
\text { vulnerable }\end{array}$ & $\begin{array}{l}\text { Moderately } \\
\text { vulnerable }\end{array}$ & $\begin{array}{c}\text { Less } \\
\text { vulnerable }\end{array}$ & $\begin{array}{c}\text { Highly } \\
\text { vulnerable }\end{array}$ & $\begin{array}{l}\text { Moderately } \\
\text { vulnerable }\end{array}$ & $\begin{array}{c}\text { Less } \\
\text { vulnerable }\end{array}$ & $\begin{array}{c}\text { Highly } \\
\text { vulnerable }\end{array}$ & $\begin{array}{l}\text { Moderately } \\
\text { vulnerable }\end{array}$ & $\begin{array}{c}\text { Less } \\
\text { vulnerable }\end{array}$ \\
\hline $\begin{array}{l}\text { Water scarcity: facing water } \\
\text { scarcity }\end{array}$ & 0.173 & 0.155 & -0.120 & -0.071 & -0.059 & -0.068 & -0.090 & 0.067 & -0.094 & 0.024 & -0.014 & -0.015 \\
\hline $\begin{array}{l}\text { Food shortage: facing food } \\
\text { shortage for } 3 \text { months \& } \\
\text { above }\end{array}$ & 0.126 & 0.142 & -0.089 & -0.114 & -0.050 & -0.106 & $0.661^{* *}$ & 0.032 & $0.511^{*}$ & $0.740^{* * *}$ & 0.509 & 0.308 \\
\hline $\begin{array}{l}\text { Conflict occurrence: facing } \\
\text { conflict }\end{array}$ & $0.260^{* * *}$ & $0.236^{* *}$ & $0.170^{* * *}$ & 0.052 & 0.033 & 0.056 & 0.126 & -0.076 & 0.073 & -0.133 & 0.042 & 0.076 \\
\hline
\end{tabular}

Source: Field Survey, 2014

Note: $* * *$ significant at $1 \%, * *$ significant at $5 \%, *$ significant at $10 \%$

$* * * * 4$ timads are equal to 1 hectare

$* * * * *$ Tropical Livestock Unit (TLU) conversion factors: camel $=1$, cattle $=0.7$, horse $=0.8$, mule $=0.7$, donkey $=0.5$, sheep/goat $=0.1$, chicken $=0.01$ (Source: FAO, 1987).

\section{Drought Occurrence Frequency}

As indicated in Table 8, yearly drought occurrence frequency increases significantly the probability of vulnerability of highly, moderately and less vulnerable group of households by 33.4, 32.5 and 22.3 percent respectively in highland mixed farming agro-ecosystem. Similarly, yearly drought occurrence frequency increases significantly the probability of vulnerability of highly vulnerable group of households by 29.9 percent in pastoral agro-ecosystem (Table 8). This might be that when there is yearly occurrence of drought, households become more vulnerable since they face crop failure and livestock death.

\section{Crop Failure}

Crop failure increases significantly the probability of vulnerability of moderately vulnerable group of households by 12.8 percent in highland mixed farming agro-ecosystem (Table 8). Crop failure also increases significantly the probability of vulnerability of highly, moderately and less vulnerable group of households by $13,9.7$ and 13.8 percent respectively in lowland mixed farming agro-ecosystem (Table 8). Key informants and focus group discussion participants have argued that the poor have no irrigation access and face crop failure intermittently. Moreover, key informants and focus group discussion participants have argued that crop failure makes highly vulnerable group of households more vulnerable, as they do not have reserve for the coming year leading a subsistence life.

\section{Livestock Death}

Livestock death increases significantly the probability of vulnerability of highly, moderately and less vulnerable group of households by 56.8, 47.1 and 54.5 percent respectively in agro-pastoral agro-ecosystem (Table 8). Similarly, livestock death increases significantly the probability of vulnerability of highly, moderately and less vulnerable group of households by $68.5,41.4$ and 68 percent respectively in pastoral agro-ecosystem (Table 8 ). Key informants and focus group discussion participants have argued that it is the households who have a large amount of livestock usually face more livestock deaths due to shortage of water and fodder resulted from climate change impacts like drought. In relation to this, Tesso et al. (2012) indicated that households who lose their livestock, lack the capacity to continue their livelihood operation after disaster shock is over. This is because they have already deteriorated their operational capacity.

\section{Food Shortage}

Food shortage increases significantly the probability of vulnerability of highly and less vulnerable group of households by 66.1 and 51.1 percent respectively in highland mixed farming agro-ecosystem (Table 8). Food shortage also increases significantly the probability of vulnerability of highly vulnerable group of households by 74 percent in lowland mixed farming agro-ecosystem (Table 8). This might be that the highly vulnerable groups of households are usually food insecure, which in turn makes them more and more vulnerable to climate change impacts particularly drought.

\section{Conflict}

Table 8 also shows that conflict occurrence increases significantly the probability of vulnerability of highly moderately and less vulnerable group of households by $26,23.6$ and 17 percent respectively in highland mixed farming agro-ecosystem. This might be that when there is conflict, highly vulnerable group of households could be highly affected as they lead subsistence way of life.

In conclusion, the findings show that there are households who are highly vulnerable in the less vulnerable agro-ecosystem [lowland mixed agro-ecosystem], and there are households who are less vulnerable in the highly vulnerable agro-ecosystem [agro-pastoral agro-ecosystem]. This shows that in addition to striving to make agroecosystems more adaptive, it is also necessary to develop the capacity of individual households.

Furthermore, though different factors affect different group of households, some factors are affecting all 
group of households in different agro-ecosystems. For instance, water access for irrigation, saving and conflict occurrence affects all group of households in highland mixed farming agro-ecosystem though the magnitude differs.

\section{CONCLUSIONS AND POLICY IMPLICATIONS}

\section{Conclusions}

Environmental contexts have influenced agro-ecosystems and households' vulnerability to climate change. For instance, above $1{ }^{\circ} \mathrm{C}$ temperature increase which is a threshold level (IPCC, 2014) is found in Lalibela and Dubti stations during the last 20-30 years showing that such temperature increase has caused different negative impacts in the study areas.

Lowland mixed farming agro-ecosystem is less vulnerable since it is the most adaptive and the least exposed compared to others. By contrast, agro-pastoral agro-ecosystem is most vulnerable because it is the least adaptive and the highly exposed when compared to others. A study conducted by Tesso et al. (2012) also confirmed that lowland agro-ecology is less vulnerable compared to midland and highland agro-ecologies because of better experience under stressful conditions, larger farm size ownership, better fertility level of farmlands, and better size of land under irrigation.

However, not all households in lowland mixed farming agro-ecosystems are less vulnerable and not all households in agro-pastoral agro-ecosystems are more vulnerable. Consequently, the findings show that there are households who are highly vulnerable in the less vulnerable agro-ecosystem [lowland mixed agro-ecosystem] and there are households who are less vulnerable in the highly vulnerable agro-ecosystem [agro-pastoral agroecosystem]. This shows that in addition to striving to make agro-ecosystems more adaptive, it is also necessary to develop the capacity of individual households. This was also supported by Deressa et al. (2008) indicating that interventions should focus on local levels, especially district or village levels [to address individual households], where actual dynamics of vulnerability to climate change take place.

Furthermore, determining factors affect highly, moderately and less vulnerable group of households differently in the studied agro-ecosystems. For instance, taking credit has decreased the vulnerability of highly vulnerable group of households while increasing the vulnerability of moderately and less vulnerable group of households though argued differently by key informants. A key informant has argued that if unfortunately, the livestock purchased by the credit is dead due to some diseases, poor households forced to pay the money back as they are considered they did it deliberately while the better off households are exempted.

\section{Policy Implications}

The results imply that exposure of a locality to long term changes in climate variables and occurrences of drought is the most important component to determine the overall vulnerability of the locality. However, biophysical elements determining the exposure like temperature, rainfall and drought are beyond the immediate influence of the policy makers. Of the three components of vulnerability, adaptive capacity has direct policy implications though improving the adaptive capacity also has indirect implications on improving the sensitivity of the community. For example, improving the irrigation schemes in a certain locality/agro-ecosystem decreases the crop failure due to droughts. Similarly, creating opportunities for non-farm income in different agro-ecosystems reduces the extensive dependence of households on natural resource based livelihoods, thereby reducing their sensitivity towards climate change and its extremes like drought. Thus, improving the adaptive capacity of these vulnerable households reduces their sensitivity and finally decreases their overall vulnerability. Hence, the concerned organs should work jointly to improve the adaptive capacity of households/agro-ecosystems in the study sites.

Unit of analysis is found the most crucial issue to examine vulnerability to climate change. Accordingly, when the study population is analyzed using agro-ecosystem and households as a unit of analysis, it has given a different picture. During system level analysis, it was found that lowland mixed farming and agro-pastoral agroecosystems are less and highly vulnerable respectively compared to other studied agro-ecosystems. However, at household level analysis, not all households in lowland mixed farming agro-ecosystem are less vulnerable and not all households in agro-pastoral agro-ecosystem are highly vulnerable. This implies that there should be specified adaptation policy for different agro-ecosystems, and if possible, specific programs, projects and interventions should be designed to address different vulnerable groups of households as the less, moderate and highly vulnerable groups of households are affected differently by various determining factors such as credit taking and access to irrigation water. Moreover, different researchers should conduct vulnerability analysis to climate change using different units of analysis to get the real effect of climate change in a certain locality.

Conflict of Interest: There is no conflict of interest

\section{REFERENCES}

Abson, D. J., Dougill, A. J., \& Stringer, L. C. (2012). Using Principal Component Analysis for information-rich 
socio-ecological vulnerability mapping in Southern Africa. Applied Geography, 1-10.

Acquah, H. D. (2011). Farmers Perception and Adaptation to Climate Change: A Willingness to Pay Analysis. University of Cape Coast, Cape Coast, Ghana.

Adger, W. N. (2006). Vulnerability. Global Environmental Change, 16(3), 268-281.

Adger, W. N., and Vincent, K. (2005). Uncertainty in Adaptive Capacity. C R Geosciences, 337, 399 - 410.

Amhara National Regional State, Bureau of Agriculture. (2014). Crop Development and Protection Package for Drought Prone Areas. Bahir Dar, Ethiopia.

Anderson, S., Morton, J., and Toulmin, C. (2010). Climate Change for Agrarian Societies in Drylands: Implications and Future Pathways In Mearns and Norton (ed.). 2010: Social Dimensions of Climate Change. Equity and Vulnerability in a Warming World. NewYork.

Assefa, K. (2009). Overview of Climate Change in Ethiopia. National Meteorological Agency. Addis Ababa, Ethiopia.

Atinkut, B., and Mebrat, A. (2016). Determinants of farmers choice of adaptation to climate variability in Dera woreda, south Gondar zone, Ethiopia. Environmental Systems Research, 5, 6.

Balew, S., Agwata, J., and Anyango, S. (2014). Determinants of Adoption Choices of Climate Change Adaptation Strategies in Crop Production by Small Scale Farmers in Some Regions of Central Ethiopia. Journal of Natural Sciences Research, 4(4), 2014.

Berg, L. (2009). Qualitative Research Methods for the Social Sciences. A Pearson Education Company. USA.

Bewket, W. (2012). Climate change perceptions and adaptive responses by smallholder farmers in central highlands of Ethiopia, International Journal of Environmental Studies, 69(3), 507-523.

Boko, M., Niang, I., Nyong, A., Vogel, C., Githeko, A., Medany, M., Osman-Elasha, B., Tabo, R., and Yanda, P. (2007). Africa. Climate Change 2007: Impacts, Adaptation and Vulnerability. Contribution of Working Group II to the Fourth Assessment Report of the Intergovernmental Panel on Climate Change, M.L. Parry, O.F. Canziani, J.P. Palutikof, P.J. van der Linden and C.E. Hanson, Eds., Cambridge University Press, Cambridge UK, 433-467.

Brooks, N. (2003). Vulnerability, risk and adaptation: A conceptual framework. Tyndall Centre for Climate Change Research and Centre for Social and Economic Research on the Global Environment (CSERGE) School of Environmental Sciences, University of East Anglia.

CSA. (2007). Ethiopian Population and Housing Census. Addis Ababa, Ethiopia.

Cutter, S. L., Boruff, B. J., and Shirley, W. L. (2003). Social vulnerability to environmental hazards. Social Sciences Quarterly, 84(2), 243-261.

Dawson, C. (2009). Practical Research Methods: A user-friendly guide to mastering research techniques and projects. How to Books. UK.

De Vaus, D. (2001). Research Design in Social Research. Sage Publications, London.

Deressa, T.T. (2010). Assessment of the vulnerability of Ethiopian agriculture to climate change and farmers adaptation strategies. PhD Thesis. Faculty of Natural and Agricultural Sciences, University of Pretoria; Pretoria, South Africa.

Dessler, A. E., and Parson, E. A. (2006). The Science and Politics of Global Climate Change: A Guide to the Debate. Cambridge University Press, Cambridge, New York, Melbourne, Madrid, Cape Town, Singapore, São Paulo.

Di Falco, S., and Veronesi, M. (2012). How African Agriculture Can Adapt to Climate Change? A Counterfactual Analysis from Ethiopia: London School of Economics.

Di Falco, S., Veronesi, M., and Yesuf, M. (2011). Does Adaptation to Climate Change Provide Food security? A Micro-perspective from Ethiopia. American Journal of Agricultural Economics. Oxford University Press.

FAO. (2010). Strengthening Capacity for Climate Change Adaptation in the Agriculture Sector in Ethiopia: Proceedings of the National Workshop, Nazreth, Ethiopia.

Federal Democratic Republic of Ethiopia (FDRE). (2014). Ethiopia's Climate Resilient Green Economy: Climate Resilience Strategy for Agriculture and Forestry. Addis Ababa, Ethiopia.

Filmer, D., and Pritchett, L. H. (2001). Estimating wealth effects without expenditure data or tears: An application to educational enrollments of India. Demography, 38(1), 115-132.

Füssel, H.M. (2007). Vulnerability: A generally applicable conceptual framework for climate change research. Global Environmental Change 17, 155-167.

Gbetibouo, G. A. (2009). Understanding Farmers' Perceptions and Adaptations to Climate Change and Variability. The Case of the Limpopo Basin, South Africa.

Gebremichael, Y., and Kifle, M. (2009). Local innovation in climate-change adaptation by Ethiopian pastoralists. PROLINNOVA-Ethiopia and Pastoralist Forum Ethiopia (PFE).

Getachew, S., Tilahun, T., and Teshager, M. (2014). Determinants of Agro-pastoralists Climate change Adaptation Strategies: Case of Rayitu Woreda, Oromia Region, Ethiopia. Research Journal of Environmental Sciences, $8(6), 300-317$. 
Greene, W. H. (2003). Econometric analysis, 5th ed. Prentice Hall, Upper Saddle River, New Jersey: PrenticeHall.

Guzmán, J. M., Martine, G., McGranahan, G., Schensul, D., and Tacoli, C. (2009). Population Dynamics and Climate Change. UNFPA (United Nations Population Fund) and IIED (International Institute of Environment and Development). New York and London.

Hadgu. G., Tafesse, K., Mamo, G., and Belay, K. (2015). Farmers' climate change adaption options and their determinants in Tigray Region, Northern Ethiopia. African Journal of Agricultural Research.

Hahn, M.B., Riederer, A.M., and Foster, S.O. (2009). The livelihood vulnerability index: A pragmatic approach to assessing risks from climate variability and change-A case study in Mozambique. Global Environmental Change 19:74-88.

Intergovernmental Panel on Climate Change (IPCC). (2001). Climate change: impacts, adaptation and vulnerability. IPCC Working Group II Report. Cambridge, UK: Cambridge University Press.

Intergovernmental Panel on Climate Change (IPCC). (2014). Climate change: impacts, adaptation and vulnerability. IPCC Working Group II Report. Cambridge, UK: Cambridge University Press.

Kassa, B., Beyene, F., and Winfried, M. (2005). Coping with drought among pastoral and agro-pastoral communities in Ethiopia. Journal of Rural Development, 28, 185-210.

Kelly. P. M., and Adger, W. N. (2000). Theory and Practice in Assessing Vulnerability to Climate Change and Facilitating Adaptation. Climatic Change, 47(4), 925-1352.

Kuriakose, A. T., Bizikova, L., and Bachofen, C.A. (2009). Assessing Vulnerability and Adaptive Capacity to Climate Risks: Methods for Investigation at Local and National Level. World Bank, Washington DC.

Land Management Component. (2006). Agro-ecosystems analysis and agro-ecological zoning, a handbook. LaoSwedish Upland Agriculture and Forestry Research Program. National Agriculture and Forestry Research Institute. Vientiane, Lao PDR.

Lautze, S., Kidanu, Y., Raven-Roberts, A., Young, H., Kebede, G., and Learning, J. (2003). Risk and vulnerability in Ethiopia: Learning from the past, responding to the present, preparing for the future. Report for the U.S. Agency for International Development. Addis Ababa, Ethiopia.

Lohr, S.L. (2010). Sampling: Design and Analysis. Brooks/Cole, Cengage Learning, USA.

Maddison, D. (2006). The perception to and adaptation to climate change in Africa. CEEPA. Discussion Paper No. 10. Center for Environmental Economics and Policy in Africa. Pretoria: University of Pretoria.

Mearns, R., and Norton, A. (2010). Social Dimensions of Climate Change. Equity and Vulnerability in a Warming World. NewYork.

Mengistu. D. K. (2011). Farmers Perceptions and Knowledge of Climate Change and their coping strategies to the related hazards: Case study from Adiha, Central Tigray Ethiopia. Agricultural sciences, 2 (2), 138-145.

Ministry of Agriculture (MoA). (2000). Agro-ecological zonations of Ethiopia. Addis Ababa, Ethiopia.

Mulatu, N. (2013). Determinants of Farmers' Preference for Adaptation Strategies to Climate Change: Evidence from North Shoa Zone of Amhara Region. Munich Personal RePEc Archive.

National Meteorological Services Agency (NMA). (2007). National Adaptation Program of Action for Ethiopia. National Meteorological Agency, Addis Ababa, Ethiopia.

Negatu, W., Hassen, A., and Kebede, A. (2011). A comparative Analysis of Vulnerability of Pastoralists and Agropastoralists to Climate Change: A Case study in Yabello Woreda of Oromia Region, Ethiopia. Ethiopian Journal of Development Research, 33 (1), 61-95.

Opiyo, F.O., Wasonga, O. V., and Nyangito, M. M. (2014). Measuring household vulnerability to climate-induced stresses in pastoral rangelands of Kenya: Implications for resilience programming. Pastoralism: Research, Policy and Practice, 4,10.

Orindi, V., Ochieng, A., Otiende, B., Bhadwal, S., Anantram, K., Nair, S., Kumar, V., and Kelkar, U. (2006). Mapping climate vulnerability and poverty in Africa: Report to the Department for International Development, ILRI, Nairobi, Kenya.

Pastoralist Community Development Project (PCDP). (2005). Social Analysis and Indigenous Livelihood Strategies in Afar Pastoral Communities. Addis Ababa: Federal Project Coordination Unit.

Riché, B., Hachileka, E., Awuor, C. B., and Hammill, A. (2009). Climate - related vulnerability and adaptive capacity in Ethiopia's Borana and Somali communities. Final assessment report. Save the Children UK and CARE International.

Simane, B., Zaitchik, B. F., and Ozdogan, M. (2013). Agro-ecosystem Analysis of the Choke Mountain Watersheds, Ethiopia. Sustainability, 5, 592-616.

Stern, N. (2007). The Economics of Climate Change: The Stern Review. Cambridge University Press, Cambridge, UK, pp. 712.

Stige, L.C., Stave, J., Chan, K., Ciannelli, L., Pattorelli, N., Glantz, M., Herren, H., Stenseth, N. (2006). The effect of climate variation on agro-pastoral production in Africa. PNAS, 103, 3049-3053.

Tadesse, T., Hassan, R.M., and Ringler, C. (2008). Measuring Ethiopian Farmers' Vulnerability to Climate Change 
Across Regional States. International Food Policy Research Institute (IFPRI).

Teshome, M. (2014). A Comparative Study of Farmers Vulnerability and Adaptation to Climate Change in Three Agro-ecologies of Northwest Ethiopia. PhD thesis, Addis Ababa University, Addis Ababa, Ethiopia.

Tesso, G., Emana, B., and Ketema, M. (2012). Analysis of vulnerability and resilience to climate change induced shocks in North Shewa, Ethiopia. Agricultural Sciences, 3(6), 871-888.

UN OCHA Pastoralist Communication Initiative. (2007). The Future of Pastoralism in Ethiopia.

Vincent K., Cull, T., Chanika, D., Hamazakaza, P., Joubert, A., Macome, E., Mutinhodza-Davies, C. (2013). Farmers response to climate variability and Change in Southern Africa-is it coping or adaptation? Climate Development, 5(3), 194-205.

Vincent, K. (2004). Creating an index of social vulnerability to climate change for Africa. Working Paper 56. Norwich: Tyndall Center for Climate Change Research.

Vincent, K. (2007). Uncertainty in adaptive capacity and the importance of scale. Global Environmental Change, $17(1), 12-24$.

World Bank. (2003). Ethiopia: Risk and Vulnerability Assessment. Draft Report. Washington DC.

World Bank. (2006). Reengaging in Agricultural Water Management: Challenges and options. The World Bank, Washington DC.

World Bank. (2010). Development and Climate Change. The Social Dimensions of Climate Change Adaptation in Ethiopia. Washington DC.

World Development Report (WDR). (2010). Development and Climate Change. World Bank. NewYork. 